\title{
KETERAMPILAN GURU SD KRISTEN "X" SURABAYA DALAM MENOLONG MURID SD BELAJAR DI KELAS BERDASARKAN PENDIDIKAN KRISTEN
}

\author{
Nita Agnesia Prana Putri \\ Program Studi Pendidikan Guru Sekolah Dasar, \\ Universitas Kristen Petra - Surabaya \\ Email: nitaagnesia14@gmail.com
}

\begin{abstract}
ABSTRAK
Keterampilan guru adalah kemampuan yang dapat dilakukan oleh guru untuk menolong para murid belajar di dalam kelas. Sebagai guru Kristen, keterampilan yang dimiliki dapat digunakan untuk menolong para murid belajar di dalam kelas sesuai dengan pendidikan Kristen. Keterampilan yang dimaksud adalah keterampilan dalam hal bertanya, keterampilan melakukan variasi, keterampilan dalam memberikan penguatan dan keterampilan dalam hal menjelaskan. Penelitian ini bertujuan untuk mendeskripsikan keterampilan guru Kristen di SD Kristen " $X$ " untuk menolong murid belajar di kelas berdasar teori yang dikemukakan oleh Debora dan Han pada tahun 2020. Penelitian ini mengambil data melalui observasi dan wawancara. Hasil penelitian ini menunjukkan bahwa guru di SD Kristen "X" Surabaya telah menjalankan pendidikan Kristen dengan benar melalui keterampilan mengajar yang dilakukan.
\end{abstract}

Kata kunci: Guru Kristen, Keterampilan Mengajar Guru, Murid, Pendidikan Kristen.

\begin{abstract}
Teacher skills are abilities that can be done by teachers to help students learn in the classroom. As a Christian teacher, the possessed skills can be used to help students learn in the classroom based on Christian education. The skills in question are questioning skills, variations skills, reinforcement skills and explaining skills. The aim of this study is to describe the skills of a Christian teacher at SD Kristen " $X "$ to help students learn in a class based on the theory proposed by Debora and Han in 2020. This study took data through observations and interviews. Meanwhile, for data collection, researchers used tools in the form of interviews, and written notes. The results of this study indicate that teachers at SD Kristen " $X$ " Surabaya have carried out Christian education correctly through their teaching skills
\end{abstract}

Keywords: Teacher Skills, Helping Students Learn in Class, Christian Education

\section{PENDAHULUAN}

Pendidikan Kristen di kelas adalah proses untuk memperkenalkan kebenaran Firman Tuhan kepada para murid. Proses memperkenalkan kebenaran Firman Tuhan kepada para murid dapat dilakukan oleh seorang guru Kristen, yaitu guru yang bersedia membagikan kasih dan kebenaran Firman Tuhan karena ia telah menerima kasih Tuhan, dan melakukan kebenaran Firman Tuhan (Tampenawas et al., 2020). Dalam hal ini, guru Kristen dapat menggunakan keterampilan mengajar di kelas untuk memperkenalkan kebenaran Firman melalui seluruh kegiatan pembelajaran di kelas. Keterampilan mengajar adalah salah satu peran penting yang dapat dilakukan guru untuk mendidik murid dalam proses pembelajaran di kelas. Dalam proses pembelajaran, keterampilan yang guru miliki dapat digunakan untuk mendidik murid dalam mengenal kebenaran Firman Tuhan melalui seluruh proses pembelajaran yang dilakukan guru di dalam kelas. Dalam hal ini, guru yang dimaksud adalah guru Kristen. Peran seorang guru Kristen tidak lepas dari tujuan guru Kristen sebagai rekan kerja Allah. Sebagai rekan kerja Allah guru Kristen memiliki tanggung jawab mengajarkan kebenaran (Debora \& Han, 2020). Guru dapat menggunakan ide, pikiran, akal dan kreativitasnya dalam melaksanakan, mengubah atau menciptakan proses pembelajaran di kelas menjadi lebih bermakna (Yulianingsih \& Stefanus, 2019). Oleh karena itu, guru harus memiliki keterampilan yang baik supaya tujuan pendidikan Kristen dapat dilaksanakan dengan baik. Keterampilan merupakan hal penting yang harus dimiliki guru. Selain untuk mendidik murid sesuai dengan pendidikan Kristen, keterampilan yang guru miliki juga dapat menolong murid dalam proses pembelajaran di dalam kelas. Guru dapat menolong 
murid menjalani proses belajar di dalam kelas dengan cara memberikan bimbingan, latihan, bahkan teladan bagi para muridnya (Auligia, 2018). Jika guru mampu menggunakan keterampilan yang ia miliki dengan tepat, guru akan mampu menolong murid untuk belajar di kelas sehingga mampu memotivasi, mengajarkan ilmu dengan baik dan guru mampu membuat suasana belajar di kelas menjadi efektif (Surani, 2018)

Pada bulan Agustus 2019 - November 2019, peneliti melakukan praktik magang atau Pemantapan Guru Muda (PGM) dalam bentuk observasi. Berdasarkan hasil observasi, peneliti menemukan ada sesuatu yang menarik, yaitu ada guru SD Kristen "X" Surabaya Surabaya yang mampu menggunakan keterampilan mengajar dengan baik, sehingga ia mampu membuat kelas yang para muridnya terkenal ramai, menjadi sangat tenang dan efektif. Dalam observasi tersebut, peneliti memiliki kesempatan untuk mengamati secara langsung bagaimana guru tersebut memberikan perhatian, bimbingan dan latihan soal, kemudian mengamati bagaimana guru mengajak para murid untuk serius ketika sedang renungan pagi, konsisten mengajarkan kedisiplinan melalui penguatan, menjadi pendengar yang baik ketika murid bertanya atau bercerita tentang suatu hal, menjelaskan materi dengan cara berkomunikasi yang jelas, padat, variatif dan tidak lupa mengingatkan murid untuk berusaha memberikan yang terbaik dari dalam dirinya, seperti melakukannya untuk Tuhan. Menurut jurnal yang dituliskan oleh Yulianingsih \& Stefanus (2019), apa yang dilakukan seorang guru di SD Kristen " $X$ " Surabaya merupakan hal yang tepat. Dalam jurnal tersebut, dituliskan bahwa guru dapat dikatakan terampil jika mampu menguasai keterampilan dalam menjelaskan, memberi pertanyaan, memberi penguatan dan mampu membuat variasi dalam proses mengajar di kelas.

Penelitian ini dilakukan di SD Kristen "X" Surabaya. Peneliti memilih melakukan penelitian di Sekolah Dasar Kristen "X" Surabaya Surabaya karena penulis ingin menemukan lebih dalam tentang bagaimana guru di SD Kristen " $X$ ” Surabaya berperan sebagai guru Kristen dalam hal mengajar, untuk menolong murid SD belajar di kelas berdasarkan pendidikan Kristen. Oleh karena itu, peneliti ingin memilih guru A sebagai subjek untuk meneliti lebih jauh tentang bagaimana keterampilan guru Kristen di SD Kristen "X" Surabaya ini mampu menjalankan perannya dengan benar. Harapannya, penelitian ini dapat menjelaskan keterampilan guru SD Kristen " $X$ " Surabaya dalam menolong murid SD belajar di kelas berdasarkan pendidikan Kristen dan dapat menjadi teladan bagi banyak orang.

\section{LANDASAN TEORI}

\subsection{Pendidikan Kristen}

Dalam penelitian ini, penulis menggunakan beberapa teori, yaitu : Pendidikan merupakan proses yang bertujuan untuk mentransformasi seseorang dengan menanamkan nilai dan pengetahuan (Bonde,2020). Dalam menjalankan prosesnya, pendidikan Kristen harus berdasar pada Alkitab yang menjadikan Kristus sebagai pusat dari seluruh proses pembelajaran yang ada (Widianing, 2018). Proses pendidikan yang menjadikan Alkitab (Firman Allah yang tertulis) sebagai dasar akan menolong seseorang mengenal karakter Kristus dan mengalami perjumpaan secara pribadi dengan Tuhan Yesus (Yulianingsih \& Stefanus, 2019).

\subsection{Guru Kristen}

Pada dasarnya seorang guru Kristen diberi karunia dari Tuhan untuk melaksanakan tugas dan tanggungjawab sebagai seorang pengajar dan pembimbing (Telaumbanua, 2018). Guru Kristen sebagai pembimbing seharusnya mampu menempatkan diri dengan tepat dalam hal pembimbingan agar bisa menjalin sebuah komunikasi yang baik dengan siswa yang dibimbing (Duka, 2018). Bukan hanya sekedar karunia, namun seorang guru Kristen harus menyadari bahwa profesi sebagai guru Kristen merupakan sebuah panggilan untuk melayani Tuhan dalam dunia Pendidikan (Prijanto, 2017, p. 102). Oleh sebab itu, seorang guru Kristen harus bisa memahami dirinya sebagai seorang pengajar dalam kerangka panggilan Tuhan dan karunia yang diberikan Tuhan padanya. Peran seorang guru Kristen tidak lepas dari tujuan guru Kristen sebagai rekan kerja Allah. Sebagai rekan kerja Allah guru Kristen memiliki tanggung jawab mengajarkan kebenaran (Debora \& Han, 2020).

\subsection{Keterampilan Guru Untuk Menolong Murid Belajar di Dalam Kelas}

Menurut Agustina (2017) dalam menjalankan peran sebagai guru, seorang guru dapat dikatakan sukses apabila melakukan beberapa hal yaitu : menghargai murid, bersikap sabar, mendengarkan dan tidak mendominasi, bersikap sederajat, bersikap akrab dan membaur, tidak berusaha menceramahi, berwibawa, tidak pilih kasih, bersikap positif, bersikap terbuka, seluruh keterampilan. Menurut Jaya (2017) keterampilan yang dimiliki guru dapat menolong murid untuk belajar dengan baik dan menyenangkan. Berikut adalah ciri-ciri seorang guru berhasil menolong murid dalam proses pembelajaran 
di dalam kelas menurut Anwar (2018):

1. Murid memperhatikan guru atau tidak.

2. Murid semangat mengikuti proses pembelajaran atau tidak.

3. Murid memahami atau tidak memahami pertanyaan yang ditanyakan guru.

4. Murid memiliki hasil belajar yang sesuai dengan target guru.

5. Murid mampu menunjukkan akhlak yang baik.

6. Murid mendapatkan hasil yang baik dari hasil laporan ketika guru lain melakukan supervisi.

Keberhasilan dalam mengajar murid tidak hanya ditentukan oleh faktor motivasi, keaktifan murid, dan kelengkapan fasilitas saja, melainkan perlu adanya keterampilan guru untuk mendukung keberhasilan dalam mengajar murid Lestari, 2018). Beberapa keterampilan yang harus dimiliki guru untuk mendukung keberhasilan dalam proses mengajar menurut Yulianingsih \& Stefanus (2019) yaitu keterampilan membuka pelajaran di kelas dengan menarik, keterampilan bertanya, keterampilan dalam memberi penguatan, keterampilan mengadakan variasi, keterampilan menjelaskan, keterampilan menutup kelas

\section{Metode Penelitian}

\subsection{Desain Penelitian}

Daftar penelitian ini penulis menggunakan beberapa metode, yaitu: penelitian ini menggunakan pendekatan kualitatif. Hengki Wijaya (2018) mengatakan bahwa pengertian dari penelitian kualitatif adalah metode penelitian yang berlandaskan pada filsafat postpositivisme yang menekankan pada cara berpikir yang induktif yang menghasilkan data deskriptif. Hal tersebut sama dengan jenis penelitian yang dilakukan oleh peneliti dalam skripsi ini, yaitu jenis penelitian dengan metode deskriptif.

Jenis penelitian yang digunakan dalam penelitian ini adalah penelitian kualitatif deskriptif. Menurut Muslich (2007) pengertian dari deskripsi adalah "karangan yang berisi gambaran mengenai suatu hal atau keadaan sehingga pembaca seolah-olah melihat, mendengar atau merasakan hal tersebut" (Wati, Ilyas, Sulistyowati, 2017, p.295). Oleh sebab itu, penelitian kualitatif yang peneliti lakukan ini akan memaparkan gambaran dari realita yang peneliti amati melalui kegiatan di SD Kristen " $X$ " Surabaya Surabaya dan juga wawancara secara mendalam dari subjek penelitian beserta para informan yang peneliti pilih terhadap keterampilan guru SD Kristen " $X$ " Surabaya dalam menolong murid SD belajar di kelas berdasarkan pendidikan Kristen.

Dalam penelitian ini, peneliti melakukan penelitian tentang keterampilan guru SD Kristen " $X$ " Surabaya dalam menolong murid SD belajar di kelas berdasarkan pendidikan Kristen melalui kegiatan magang atau PGM (Pemantapan Guru Muda) yang dilaksanakan pada bulan Agustus 2019 - bulan November 2019. Kemudian melakukan proses wawancara kepada subjek penelitian dan para informan pada bulan Mei 2021 yang dilakukan secara daring karena sedang berada dalam situasi pandemi covid-19. Dalam melakukan proses wawancara, peneliti melakukannya secara online menggunakan aplikasi zoom.

\subsection{Subyek Penelitian}

Subyek penelitian dalam penelitian ini merupakan guru Tematik kelas 5 Sekolah Dasar Kristen "X" Surabaya dan beberapa rekan lain sebagai informan yaitu 2 guru yang mengajar di jenjang kelas 5 serta 1 kepala sekolah SD Kristen "X" Surabaya. Informan penelitian membantu mengkonfirmasi kebenaran data dari subjek penelitian.

\subsection{Analisis Data}

Penelitian ini menggunakan pendekatan kualitatif. Dengan menggunakan metode observasi di sekolah, wawancara dengan subjek dan informan penelitian.

\section{HASIL DAN PEMBAHASAN}

Peneliti memaparkan data mengenai keterampilan guru SD Kristen "X" Surabaya dalam menolong murid SD belajar di kelas berdasarkan pendidikan kristen. Berikut adalah uraian temuan data peneliti.

\subsection{Pengertian Guru Kristen}

Pengertian guru Kristen menurut Guru SW adalah mendoakan keselamatan setiap muridnya. Guru SW mengungkapkan bahwa beliau tidak hanya mendidik secara akademik saja, tetapi mendidik secara karakter dan mendoakan para murid sebagai anak-anak yang sudah dipercayakan Tuhan kepada guru SW. "saya selalu mendoakan murid saya dalam tiga hal, yaitu karakter/perilaku mereka, masa depan, dan yang utama itu keselamatan untuk mereka sampai besar dan tua. Karena percumah jika punya karakter yang baik, berhasil, tetapi kalau meninggalkan Tuhan itu sia-sia" (SW, personal communication, Mei 30, 2021). Sedangkan pengertian guru Kristen menurut Guru IC mengungkapkan bahwa sebagai guru tidak hanya bertugas untuk mengajar, tidak hanya mendidik biasa tetapi bisa mengubah dunia murid yang dapat berguna untuk mereka suatu hari nanti, terlebih lagi guru Kristen harus mempersiapkan murid dan berusaha menolong murid supaya murid mengenal siapa Juru Selamat kita, yaitu Tuhan 
Yesus. Melalui data ini, peneliti menemukan bahwa apa yang dilakukan guru SW sudah mencerminkan seorang guru Kristen karena beliau tidak hanya memiliki kerinduan untuk mencerdaskan muridnya, namun memiliki kerinduan supaya para murid mengerti tentang keselamatan dan mereka mau percaya kepada Yesus. Hal yang serupa juga dikemukakan oleh guru IC sebagai informan dari penelitian ini.

"Prinsip saya menjadi guru adalah saya tidak ingin hanya sekedar mengajar dan mendidik saja, melainkan ingin mengubah dunia mereka menjadi sesuatu yang nantinya dapat bermanfaat untuk mereka. Meskipun saya tahu pada kenyataannya, karakter tidak dapat diubah hanya dalam waktu satu tahun. Tetapi saya percaya jika suatu saat ketika saya melihat hidup mereka berguna, itu adalah suatu kebanggaan untuk saya. Dan yang terakhir dan terpenting dari semua itu adalah mereka tau kemana mereka harus pulang, yaitu kepada Yesus" (IC, personal communication, Mei 30, 2021). Pernyataan guru IC juga sesuai dengan teori yang dikemukakan oleh

Selain itu pengertian guru Kristen menurut Guru $\mathrm{AB}$ adalah seorang pendidik yang mampu menanamkan nilai-nilai Kekristenan dan mendidik mereka secara karakter, kepribadian, materi yang disampaikan, kemudian tidak berfokus pada hasil atau nilai. "Menjadi seorang guru adalah panggilan saya dan saya harus memiliki keterampilan dalam mengajar, dan ketika saya sudah bergabung di sebuah institusi, saya harus beradaptasi untuk menyesuaikan kebudayaan di tempat saya bekerja. Sebagai guru, tugasnya tidak hanya mengajar dan mendidik, tetapi harus memiliki perhatian dan menanamkan nilainilai Kekristenan kepada para murid. Harapannya adalah supaya murid memiliki kesan yang dapat terus diingat, bagaimana harus menghidupi dan memaknai nilai-nilai Kristen dalam hidup mereka" (AB, personal communication, Mei 31, 2021)

Dan pengertian guru Kristen menurut Guru SiC adalah sebuah panggilan hidup. Guru Kristen adalah pendidik yang harus memiliki kerinduan besar untuk menolong murid mengenal Tuhan. "ketika saya berdiri di depan anak-anak, berbagi ilmu dengan mereka, rasanya kok berbinar-binar ya, saya merasa ada sukacita yang tidak bisa saya jelaskan, ketika saya menceritakan firman Tuhan dan bisa mendaratkan itu kepada mereka. Melihat mereka tertawa, mereka menangis, mereka bertanya tentang Kristus atau Alkitab, disitu ada kebahagiaan yang tidak bisa saya jelaskan"(SiC, personal communication, Mei 31, 2021)

\subsection{Keterampilan Mengajar Guru dalam Hal Bertanya}

Keterampilan bertanya merupakan salah satu hal yang dapat menolong murid untuk belajar di dalam kelas. Berdasarkan hasil observasi dan wawancara peneliti terhadap guru SW dalam melakukan proses mengajar, peneliti menemukan bahwa ketika guru SW sering mengajukan pertanyaan di dalam kelas. Harapan guru SW ketika menyampaikan pertanyaan adalah supaya murid memahami materi yang sedang dipelajari dengan baik. "ketika presentasi miss, saya tidak hanya meminta anak-anak untuk presentasi saja, namun saya akan berikan pertanyaan, biasanya saya akan berikan tiga pertanyaan untuk memastikan apakah anak itu benar-benar paham dengan materinya" (SW, personal communication, Mei 30, 2021)

Menurut (Syaripuddin, 2019, p.17) komponenkomponen bertanya yang harus dimiliki guru adalah Singkat dan jelas, adanya acuan, Pemusatan (focusing), Pindah Gilir (re-directing).

Pada saat peneliti melakukan kegiatan observasi pada PGM 1, peneliti mengamati bahwa guru SW sudah memberikan pertanyaan dengan baik. Beliau menyampaikan pertanyaan itu dengan jelas dan singkat, sehingga murid dapat menangkap maksud pertanyaan dengan benar dan mampu menjawab dengan benar. Kemudian, peneliti juga mengamati bahwa guru SW sudah adil dalam mengajukan pertanyaan kepada murid. Hal itu terlihat ketika peneliti observasi, guru SW memanggil nama salah satu murid kemudian memberi pertanyaan kepada murid tersebut mengenai materi yang sedang dipelajari. Hal yang serupa juga diungkapkan oleh guru $\mathrm{AB}$ yang menyatakan bahwa guru $\mathrm{AB}$ sudah lama menjadi partner guru SW dalam hal mengajar. Guru SW menilai bahwa:

"Beliau (Ms.SW) mengajarnya cukup interaktif, jadi cukup sering memberi pertanyaan juga kepada murid" (AB, personal communication, Mei 31, 2021).

Pada pengamatan yang peneliti lakukan di PGM 1, peneliti mengamati bahwa fungsi adanya pertanyaan bukan hanya untuk menolong murid untuk memahami materi pembelajaran pada saat itu, namun dengan adanya pertanyaan, guru dapat membangun relasi dan komunikasi dengan murid dan dapat kembali fokus belajar. Hal ini serupa dengan yang dituliskan oleh Yulianingsih \& Stefanus (2019) tentang kisah Tuhan Yesus ketika mengajar para pengikutnya dengan memberi pertanyaan. Seperti yang tertulis dalam Injil Matius 26:8 ; Matius 16:15 ; Matius 26:40b ; dan Matius 15:34. Nilai yang dapat diteladani dari beberapa kisah Yesus ketika memberi pertanyaan adalah guru harus memiliki kepekaan yang tinggi dalam melihat kebutuhan murid akan informasi. Dua cara diantaranya adalah dengan dengan cara melibatkan para murid dalam proses 
pembelajaran dan mengajukan pertanyaan yang tepat kepada murid. Sebagai seorang guru, kita dapat meneladani pengalaman Yesus yang Yesus pernah lakukan ketika mengajar murid-muridNya.

\subsection{Keterampilan Mengajar Guru dalam} Hal Memberi Penguatan

Dalam hal memberikan penguatan, peneliti menemukan bahwa guru SW banyak melakukan penguatan melalui sikap dan perkataan."Betul miss, biasanya kalau murid saya mau nurut dan taat sama saya, saya akan beri apresiasi, saya akan bilang thank you hari ini sudah mau taat" (SW, personal communication, Mei 30, 2021). Peneliti juga mengamati bahwa guru SW menggunakan keterampilan dalam memberi penguatan dengan membuat peraturan."Kalau ada anak yang ramai dan setelah diingatkan tetap ramai, biasanya saya akan pindahkan duduknya dia di dekat meja saya. Jadi dia duduk paling depan. Dan kalau dia mulai tidak fokus, biasanya saya akan tepuk pundaknya atau tangannya sambil senyum dan berkata "ayo fokus nak". Terkadang jika ada anak yang saya rasa belum siap mengikuti proses belajar, saya minta ia untuk di luar kelas menenangkan hati dan menenangkan diri. Sampai waktu ia merasa sudah cukup tenang ia bisa kembali ke kelas dan belajar. Biasanya hal -hal yang seperti itu tidak lama". (SW, personal communication, Mei 30, 2021)

Hal ini sudah sesuai dengan penjelasan yang dituliskan di sebuah jurnal yang dituliskan (Calista, Nima, dan Ardina. 2019) bahwa terdapat enam penguatan yang dapat dilakukan guru ketika melakukan proses pengajaran di kelas yaitu penguatan verbal, penguatan gestural, penguatan melalui pendekatan, penguatan sentuhan, penguatan dengan memberikan yang menyenangkan, penguatan berupa tanda atau benda.

\subsubsection{Penguatan verbal}

Dalam melakukan kegiatan belajar di kelas, Guru SW sering memberikan penguatan, baik dalam hal memberi semangat, mengingatkan, maupun memberi teguran. "Jadi saya gini saya puji dari ada event apa saya puji di grup, nah kemudian terus saya selalu ingatkan. Anak-anak kita semua ini e.. apa anak-anak yang berhikmat. Walaupun masih kecil kita perlu hikmat. Jadi perlu setiap hari anak-anak minta hikmat sama Tuhan".

\subsubsection{Penguatan gestural}

Menurut hasil pengamatan pada PGM 1 , penguatan gestural yang dilakukan guru SW adalah dengan menunjukkan ekspresi wajah dan gerakan tubuh. Misalnya tersenyum, menggelengkan kepala saat ada murid yang berperilaku tidak baik, kemudian menepuk pundak murid, dsb.

\subsubsection{Penguatan melalui pendekatan}

Guru dapat melakukan penguatan ini dengan cara mendekati anak untuk menunjukkan perhatian kepada hasil kerja, tingkah laku dan penampilan murid. Guru harus mampu membangun relasi yang baik dengan setiap murid dengan cara berkomunikasi dengan baik, mengerti bahasa anak, mengerti apa yang jadi kesukaan murid, sehingga guru lebih mudah berelasi dari hati ka hati dengan para murid (Agustina,2017).

\subsubsection{Penguatan sentuhan}

Guru dapat menyatakan penghargaan dengan menjabat tangan, atau memberikan teguran dengan menepuk pundak murid. Penguatan dengan memberikan yang menyenangkan. Dalam hal ini, guru SW sudah melakukan penguatan ini dengan cara memberi mereka apresiasi. Penguatan berupa tanda atau benda. Dalam hal memberi penguatan, guru IC juga mengungkapkan hal yang serupa :"Dalam hal mengajar, guru SW itu sangat tegas ya. Beliau itu kalau ketika mengajar, kemudian ada murid yang tidak baik, beliau akan tegur langsung. $D$ an menegurnya dengan cara mengkaitkan dalam firman Tuhan. (IC, personal communication, Mei 30, 2021)

Melalui pengamatan ketika pelaksanaan kegiatan PGM 1, serta dengan adanya wawancara dengan beberapa informan, membuktikan bahwa guru SW adalah guru yang konsisten dalam melakukan penguatan.

Pertama, guru SW menggunakan penguatan secara verbal dengan cara memberi pujian. Menurut hasil pengamatan yang peneliti lakukan, pujian akan diberikan ketika ada murid yang berhasil. Tidak hanya itu, pujian juga diberikan kepada murid yang mau taat kepada peraturan dan kepada guru. Peneliti mengamati bahwa ketika guru memberikan pujian, terutama memuji bahwa murid itu taat, berhasil, beberapa murid akan semangat ketika belajar dan mereka mau fokus mengikuti pelajaran.

Kedua, adanya penguatan secara verbal untuk menegur murid. Dari hasil pengamatan dan wawancara, peneliti menemukan bahwa guru SW memberikan penguatan secara verbal untuk menegur murid supaya fokus dalam belajar, tidak ramai dan berbicara dengan teman lainnya. Hal ini sudah diungkapkan oleh guru SW dalam proses wawancara yang peneliti lakukan :

"Tapi dari situ kita bisa lihat, anak ini fokus ndak kedepan. Nah itu biasanya langsung saya panggil”. (SW, personal communication, Mei 30, 2021)

Ketiga, penguatan verbal yang dilakukan oleh guru SW adalah dengan memberikan penjelasan tentang perumpamaan. Perumpamaan ini diberikan untuk menolong murid merenungkan hal-hal apa saya yang benar untuk dilakukan dan yang tidak benar untuk dilakukan. Misalnya ketika kelas ribut, atau ada beberapa murid yang tidak taat, melakukan hal yang 
tidak menyenangkan, guru SW akan mengingatkan para murid dengan perumpamaan sebagai berikut :"Saya selalu menanamkan kepada mereka perumpamaan tentang petani yang berhikmat dan petani yang bodoh. Petani yang berhikmat adalah petani yang mau menanam biji buah yang sehat. Tetapi petani yang bodoh memilih untuk menanam biji buah yang tidak baik. Akhirnya, setelah biji itu tumbuh, petani yang berhikmat menuai hasil yang baik, buah yang enak dan segar. Sedangkan petani yang bodoh menuai hasil buah yang tidak enak" (SW, personal communication, Mei 30, 2021)

Guru SW menjelaskan bahwa petani adalah lambang dari hidup kita, biji buah adalah pilihan kita, dan hasil dari biji yang sudah di tanam adalah perbuatan kita. Guru SW sering mengingatkan para muridnya tentang perumpamaan ini. Menurut hasil pengamatan peneliti pada PGM 1, penguatan verbal yang diberikan guru SW tentang perumpamaan ini sangat menolong murid untuk belajar di dalam kelas.

Hal yang terjadi setelah guru SW mengingatkan tentang perumpamaan adalah para murid di kelas guru SW menjadi sangat tertib dan mereka bisa belajar di kelas dengan baik. Hal ini juga diakui oleh Ms.SiC yang pernah melakukan pengamatan di kelas guru SW. Beliau menyatakan bahwa :

"kami itu ada 6 enam paralel gitu ya. E... dibanding dengan kelas yang lain kelasnya Ms.SW ini yang paling tertib gitu, iya paling tertib" (SiC, personal communication, Mei 31, 2021)

Berkaitan dengan memberikan penguatan menggunakan perumpamaan, Yulianingsih \& Stefanus (2019) menuliskan kisah Tuhan Yesus ketika mengajar dengan perumpamaan tentang talenta dalam Injil Matius 35 : 14 - 30. Melalui kisah tersebut, guru dapat meneladani Yesus dengan mengembangkan keterampilan penguatan kepada murid. Hal itu dilakukan supaya murid merasa dihargai, dikasihi, dan termotivasi untuk melakukan suatu hal yang benar ketika mendengar penguatan positif dari guru.

4.3.5 Keterampilan mengajar guru dalam hal menggunakan variasi

Dalam melakukan proses mengajar di dalam kelas, guru SW sudah menerapkan beberapa variasi. Contohnya, guru SW membuat lomba di pertengahan proses pembelajaran, guru SW juga melakukan sedikit permainan supaya murid bisa tertarik dan kembali fokus."Ketika mengajar di kelas, biasanya saya menggunakan banyak cara miss. Saya tidak hanya menjelaskan, tapi terkadang saya menggunakan games kecil berupa lomba" (SW, personal communication, Mei 30, 2021) Pendapat yang serupa juga diungkapkan oleh guru IC, AB dan SiC: "Melalui cara mengajar dan pembelajaran yang guru SW lakukan, saya melihat bahwa beliau ini orangnya kreatif. Terlihat dari bagaimana caranya membuat power point, video pembelajaran, orangnya sangat kreatif karena beliau juga pandai di dunia IT. Ada banyak ppr yang bagus, dan orangnya sangat suka dengan sesuatu yang baru" (IC, personal communication, Mei 30, 2021) "kemarin saya lihat bahwa ketika guru SW mengajarkan tentang zat campuran, beliau mampu menggunakan metode yang tidak menyulitkan siswa" (AB, personal communication, Mei 31, 2021) "Beliau banyak melakukan praktik dan anak-anak sangat senang. Dan beliau mengajarnya juga tidak terpaku pada buku, jadi menggunakan berbagai media, power point, video dan bahkan ketika pandemi ini, beliau masih menggunakan hal itu ya, meskipun tidak membuat video sendiri, tapi dia menggunakan berbagai resources" ( $\mathrm{SiC}$, personal communication, Mei 31, 2021)

Menurut (Astrisustinawati, 2017) terdapat tiga komponen atau tiga kelompok kegiatan variasi. Namun pada penelitian ini, peneliti hanya menggunakan dua dari tiga kelompok kegiatan variasi. Beberapa diantaranya adalah sebagai berikut

1. Variasi cara mengajar yang dilakukan oleh guru : pemusatan perhatian (focusing), penggunaan variasi suara (teacher voice), diam atau kesenyapan (teacher silent), variasi gerakan badan, ekspresi wajah, tatapan mata (eye contact), pergantian tempat mengajar guru ketika di kelas (teacher movement).

2. Variasi menggunakan media dan alat mengajar: variasi alat atau bahan yang dapat dilihat (visual aids), dapat didengar (auditif aids), dapat diraba (motorik), dapat didengar dan di raba (audio visual aids).

Dalam menggunakan variasi mengajar ini, guru SW melakukan banyak menggunakan media interaktif dan menarik supaya murid bisa belajar dengan baik di dalam kelas. Hal ini dilakukan supaya anak tidak merasa jenuh dan dapat kembali fokus belajar. Hal yang serupa dengan jurnal milik Pratiwi \& Ediyono (2019) yang menuliskan bahwa variasi adalah kegiatan yang harus dilakukan guru ketika melakukan proses pembelajaran di dalam kelas. Adapun beberapa kegiatan mengajar yang memerlukan keterampilan menggunakan variasi meliputi gaya mengajar, interaksi kepada para murid di dalam kelas, dan variasi dalam melakukan simulasi. Tujuan dilakukannya keterampilan dalam melakukan variasi ini adalah menolong murid belajar untuk tetap fokus dan mengurangi kebosanan ketika belajar di dalam kelas. "Dalam video nya juga cukup interaktif. Jadi menurut saya, beliau mampu 
menggunakan metode pembelajaran sesuai dengan muatan materi” (AB, personal communication, Mei 31, 2021)

\subsubsection{Keterampilan mengajar guru dalam hal menjelaskan.}

Menjelaskan adalah salah satu hal yang dapat menolong murid untuk bisa belajar di dalam kelas. Dalam hal menolong murid di dalam kelas, Guru SW menyampaikan proses pembelajaran dengan memberi penjelasan. "Waktu menjelaskan, saya lebih suka menggunakan hal-hal yang sederhana ya miss. Tidak harus sesuai dengan apa yang ada di buku. Dan biasanya saya akan membuat alat peraga atau gambar-gambar yang saya gambar di papan tulis. (SW, personal communication, Mei 30, 2021)

Dalam hal ini, peneliti mengamati bahwa guru SW sudah memiliki keterampilan menjelaskan yang dapat menolong murid belajar di dalam kelas karena kondisi kelas guru SW sangat tertib dan tenang. Menurut Astrisustinawati (2017), keterampilan menjelaskan adalah tindakan yang dilakukan guru untuk mengorganisasikan materi secara terencana dan sistematis, sehingga murid dapat memahami isi pesan yang disampaikan. Dalam hal menjelaskan, guru memerlukan beberapa kriteria yaitu guru menggunakan bahasa yang jelas, guru mampu berbicara dengan lancar, guru mampu mendefinisikan istilah-istilah yang teknis dan berhenti sejenak untuk mengamati respon murid, menggunakan contoh dan ilustrasi dengan tepat, pemberian tekanan pada hal-hal yang penting dengan cara penekanan suara, guru memberikan kesimpulan dan mengemukakan tujuan.

\section{KESIMPULAN}

Berdasarkan tujuan penelitian untuk mendeskripsikan keterampilan guru SD Kristen "X" Surabaya dalam menolong murid SD belajar di kelas berdasarkan pendidikan Kristen. Peneliti menyimpulkan bahwa guru kelas 5 di SD Kristen " $X$ " Surabaya sudah menjalankan keterampilan guru dalam hal memberi pertanyaan, memberikan penguatan, melakukan variasi belajar, dan melakukan keterampilan menjelaskan, sehingga hal itu dapat menolong murid untuk belajar di kelas. Selain memiliki keterampilan yang benar, hal yang perlu dilakukan guru untuk menolong murid belajar di dalam kelas adalah dengan hidup di dalam Tuhan dan menghidupi nilai-nilai kebenaran, sehingga guru dapat menolong murid belajar bukan hanya dengan keterampilan, melainkan dengan kebenaran firman Tuhan

\section{DAFTAR PUSTAKA}

Agung, I. (2017). Peran Fasilitator Guru dalam Penguatan Pendidikan Karakter. Perspektif Ilmu Pendidikan. 31(2). 106-119.

Agustina, R. (2017). Peran Guru

sebagai Fasilitator dalam Proses Pembelajaran di SMP Negeri 1 Wonosobo Kabupaten Tanggamus (Doctorial dissertation, UIN Raden Intan Lampung).

Auligia, R. (2018). No Title （表示不

$\begin{array}{llrr}\text { 可能) } & \text { [UNIVERSITAS } & \text { ISLAM } & \text { NEGERI } \\ \text { SULTAN } & \text { SYARIF } & \text { KASIM } & \text { RIAU]. } \\ \text { http://repository.uin-suska.ac.id/id/eprint/12228 }\end{array}$

Auligia, R. (2018). Peran Guru sebagai Motivator dan Fasilitator dalam Pembelajaran Ekonomi di Sekolah Menengah Atas Negeri Mandau (Doctoral dissertation, UIN Sultan Syarif Kasim Riau).

Debora, K., \& Han, C. (2020). Pentingnya Peranan Guru Kristen dalam Membentuk Karakter Siswa Dalam Pendidikan Kristen: Sebuah Kajian Etika Kristen. Diligentia: Journal of Theology and Christian Education, 2(1), 114.

Katuhu, N. (2018). Peran Guru PAK sebagai Fasilitator dalam Pembelajaran di SMP Negeri 3 Bolang Itang Timur. (Doctorial dissertation)

Lincoln, Yovana, Guba, Egon. (2008).

Naturlistic Inquiry. Beverly Hills: Sage Publication.

Rahmarwati, M. (2017). Pengaruh Peran Guru Sebagai Fasilitator Terhadap Efektivitas Belajar Siswa pada Mata Pelajaran Kearsipan Kelas X Program Keahlian Administrasi Perkantoran SMKN 11 Bandung (Doctoral Dissertation, Universitas Pendidikan Indonesia).

Rahmarwati, M., \& Suryadi, E. (2019). Guru sebagai Fasilitator dan Efektivitas Belajar Siswa. Jurnal Pendidikan Manajemen Perkantoran (JPManper),4(1), 49-54.

Suardipa, I, P. (2020). Perspektif Values Education dalam Kajian Filsafat Pendidikan Berbasis $3 N$ (Nalar, Nurani, dan Naluri). Genta Hredaya, 2(2).

Tampenawas, A. R., Ngala, E., \& Taliwuna, M. (2020). Teladan Tuhan Yesus Menurut Injil Matius dan Implementasinya Bagi Guru Kristen Masa Kini. EDULEAD: Journal of Christian Education and Leadership, 1(2), 214-231.

https://doi.org/10.47530/edulead.v1i2.44 
Aletheia Christian Educators Journal, Vol. 2, No. 2, Oktober 2021, 171-178

Tari, E. (2019). Etika Kerja Berdasarkan 2

Teologi Praktika, 1(2).

Korintus 2 : 15 - 16. Jurnal Gamaliel: 